\title{
Physical and Chemical Properties of Selected Newly Released Rice Varieties of Northern Telangana Region, India
}

\author{
R. Anitha ${ }^{1 *}$, K. Manorama ${ }^{2}$, CH. Hemamalini ${ }^{1}$ and M. Sreedhar ${ }^{2}$ \\ ${ }^{1}$ Post Graduate and Research Centre, Professor Jayashankar Telangana State Agricultural \\ University, Hyderabad, Telangana, India \\ ${ }^{2}$ Quality Control Laboratory, Professor Jayashankar Telangana State Agricultural University, \\ Hyderabad, Telangana, India \\ *Corresponding author
}

\begin{tabular}{|c|c|}
\hline \multicolumn{2}{|r|}{ A B S T R A C T } \\
\hline & \multirow{6}{*}{$\begin{array}{l}\text { Physical and chemical properties of Anjana (JGL-11118) and Pradhyumna (JGL-17004) } \\
\text { rice varieties were grown and processed in Northern Telangana State were studied. The } \\
\mathrm{L} / \mathrm{B} \text { ratio of rice varieties Anjana (JGL-11118) and Pradhyumna (JGL-17004) were } 3.62 \pm \\
0.16 \mathrm{~mm} \text { and } 3.37 \pm 0.12 \mathrm{~mm} \text {. These varieties are classified as short slender grains. } \\
\text { Volume expansion was taken as the ratio between volume of cooked rice and initial } \\
\text { volume of raw rice. V.E. values of Anjana (JGL-11118) and Pradhyumna (JGL-17004) } \\
\text { varieties were } 2.7 \mathrm{~cm} \text { and } 2.5 \mathrm{~cm} \text {. Elongation ratios of Anjana (JGL-11118) and } \\
\text { Pradhyumna (JGL-17004) rice varieties are } 1.45 \text { and } 1.48 \text {, therefore they have desirable } \\
\text { elongation ratios. Moisture content of rice varieties Anjana and Pradhyumna was } 7.85 \pm \\
0.2 \text { and } 7.21 \pm 0.12 \text { percent. Ash content of Anjana and Pradhyumna was } 0.53 \pm 0.13 \text { and } \\
0.89 \pm 0.02 \text { percent. Ash content of rice variety Pradhyumna was higher than the ash } \\
\text { content of rice variety Anjana. The protein content was } 7.9 \pm 0.0 \text { and } 7.53 \pm 0.2 \mathrm{~g} / 100 \mathrm{~g} \\
\text { respectively in Anjana and Pradhyumna. The fat content was } 0.55 \pm 0.08 \text { and } 0.59 \pm 0.06 \\
\text { g/100 g respectively in Anjana (JGL-11118) and Pradhyumna (JGL-17004). Crude fibre } \\
\text { content was } 0.39 \pm 0.10 \text { and } 0.24 \pm 0.05 \mathrm{~g} / 100 \mathrm{~g} \text { respectively in Anjana (JGL-11118) and } \\
\text { Pradhyumna (JGL-17004). Carbohydrate content of Anjana (JGL-11118) and Pradhyumna } \\
\text { (JGL-17004) was } 83.11 \pm 0.62 \text { and } 83.7 \pm 0.07 \text {. Energy values of the Anjana (JGL-11118) } \\
\text { and Pradhyumna (JGL-17004) rice were } 369.45 \pm 0.64 \text { and } 370.38 \pm 0.62 \mathrm{kcal} / 100 \mathrm{~g} \text {. Iron } \\
\text { content of rice varieties Anjana (JGL-11118) and Pradhyumna (JGL-17004) was } 0.93 \pm \\
0.04 \text { and } 0.86 \pm 0.04 \mathrm{mg} / 100 \mathrm{~g} \text {. Calcium content of rice varieties Anjana (JGL-11118) and } \\
\text { Pradhyumna (JGL-17004) was } 9.3 \pm 1.15 \text { and } 10.3 \pm 0.5 \mathrm{mg} / 100 \mathrm{~g} \text {. }\end{array}$} \\
\hline Keywords & \\
\hline & \\
\hline Article Info & \\
\hline & \\
\hline & \\
\hline
\end{tabular}

\section{Introduction}

Rice is a staple food consumed by more than half of the world population (FAOSTAT, 2014). It provides 20 percent of the world's dietary energy supply, while wheat supplies 19 percent and maize (corn) 5 percent (FAO, 2004). It is the predominant dietary energy source for 17 countries in Asia and the Pacific and 9 countries in North and South Africa. In 59 countries, an average of at least $75 \mathrm{~g}$ of rice is available per person per day (FAOSTAT, 2014).

The total population of these countries is 4.1 billion which indicates that reaching even half 
of that population would ensure a greater daily nutrient intake among 2 billion people (FFI, 2014).

Rice grain quality is of great importance for all people involved in production, processing and consumption because it has direct impact on the commercial value of the produce, consumer preference is based on appearance, milling and cooking processing and nutritional quality positive visual preference of the grain is based on grain size, shape and chalkiness while in addition traders rate recovery of whole milled grains as other crucial quality traits while deciding the price (Shobha et al., 2008).

Rice, beyond its nutritive value has got high digestibility and the least allergenic property than all other grains so it can be enjoyed by young and old alike (Betrez-Marquez et al., 2005).

Rice is the main constituent of life-saving oral rehydration solutions (ORS), and has been used for treatment of various ailments such as diarrhea, vomiting, fever, hemorrhage, chest pain, wounds, and burns.

Recent studies recommend rice as a novel food due to its high mineral content, antioxidant properties and low glycemic index for lowering the incidence of lifestyle-related diseases such as heart attack, diabetes and cancer, which have begun to assume epidemic form over the last two decades not only in urban India, but in rural India too (Rhoades, 2008).

Despite numerous studies on different varieties of rice, there is lack of published data on physical and chemical properties of newly released rice varieties of Telangana.

Hence, the present study is undertaken to assess the Physico-chemical properties of the selected newly released rice varieties.

\section{Materials and Methods}

One of the new released rice varieties viz Anjana (JGL-11118) and Pradhyumna (JGL17004) were procured from Regional Agricultural Research Station, Jagityal, Karimnagar.

\section{Experimental design}

Physical properties like grain hardness, volume expansion, 1000 kernel weight, elongation ratio, kernel length, breadth, L/B ratio and water uptake by the grains were assessed using standard procedures (Sahay and Singh, 2005).

\section{Grain hardness}

Grain hardness of the samples was determined using grain hardness tester

\section{Volume expansion}

Volume expansion of the samples was assessed by weighing $5 \mathrm{~g}$ of sample in a test tube containing $15 \mathrm{ml}$ of water and cooked for 20 minutes. Volume expansion is calculated by taking average of the 3 readings.

\section{0 kernel weight}

1000 kernel weight was determined by selecting 1000 sound kernels. The samples were weighed and repeated for 3 times and average of 3 readings was taken.

Elongation ratio $=$ Length of cooked kernel $(\mathrm{mm})(\mathrm{y}) /$ Length of uncooked kernel $(\mathrm{mm})$ (x)

\section{Kernel length, breadth, L/B ratio}

Kernel length, breadth, L/B ratio of the samples were measured using micrometer by placing the kernels horizontally and vertically. 


\section{Water uptake by the grains}

Water uptake by the grains was determined by weighing $2 \mathrm{~g}$ of sample in $100 \mathrm{ml}$ graduated centrifuge tube containing $100 \mathrm{ml}$ of water and cooked for 45 minutes. The supernatant water was transferred into a graduated cylinder after cooling and water level was noted.

Proximate analysis was conducted for the two newly released rice varieties of Northern Telangana region. Moisture content of the samples was determined using the procedure given by Association of Official Analytical Chemists (AOAC, 2005). Protein content was estimated from the crude nitrogen content of the sample determined by the Micro Kjeldhal method $(\mathrm{N} \times 6.25)($ AOAC, 2005).

Fat content was estimated as crude ether extract of the dry material using automatic Gerhardt Soxtherm extraction unit (AOAC, 2005). Crude fiber content of the samples was determined by the procedure of the Association of Official Analytical Chemists (AOAC, 2005).

Total ash was determined using the procedure documented by Association of Official Analytical Chemists (AOAC, 2005). Energy and carbohydrate content was calculated by difference method (Gopalan et al., 2004). Calcium content of the samples were determined using Titrimetric method (Siong et al., 1989). Iron content of the samples were determined using $\alpha-\alpha$ dipyridyl method respectively.

\section{Statistical Analysis}

Mean and standard deviation for three parallel replicates were calculated. Analysis of variance (ANOVA) was used to test the difference between means. (Snedcor and Cochran, 1983)

\section{Results and Discussion}

The Physico- chemical parameters like grain hardness, volume expansion, 1000 kernel weight, elongation ratio, kernel length, breadth, L/B ratio, water uptake and proximate analysis were assessed and the results are presented in tables 1 and 2 .

\section{Grain hardness}

Grain hardness of the samples was determined using grain hardness tester. Grain hardness values of Anjana (JGL-11118) and Pradhyumna (JGL-17004) was $5.40 \pm 1.78$ and $3.78 \pm 1.63$.

\section{0 kernel weight}

1000 kernel weight of Anjana (JGL-11118) and Pradhyumna (JGL-17004) was $10.26 \mathrm{~g}$ and $9.18 \mathrm{~g}$. Diako et al., (2011) found that imported brands had low 1000 grains weight. Values of 1000 grain weight between 20 and $30 \mathrm{~g}$ are considered good while those less than $20 \mathrm{~g}$ could be indicative of the presence of immature, damaged and unfilled grains. Similar results were reported by Meena et al., (2010) who pointed that the 1000 grains weight ranged between 11.36 and $20.18 \mathrm{~g}$.

Koutroubas et al., (2004) reported that grain length was negatively correlated with grain weight indicating that selection of long grains would result in a negative response of grain weight.

\section{Kernel length, breadth, $\mathrm{L} / \mathrm{B}$ ratio}

Kernel size, shape and L/B ratio are important features for grain quality assessment. The length and breadth of the rice kernels were measured using digital vernier caliper (Yamayo, Digimatic caliper). Kernel length of Anjana (JGL-11118) and Pradhyumna (JGL17004) rice varieties was $5.3 \pm 0.2 \mathrm{~mm}$ and 
$4.9 \pm 0.1 \mathrm{~mm}$. Dipti el al., (2002) reported classified grains whose lengths are greater than $6 \mathrm{~mm}$ as long, $5 \mathrm{~mm}-6 \mathrm{~mm}$ medium and less than $5 \mathrm{~mm}$ as short. By this classification, two rice samples tested were short slender grains. Breadth of Anjana (JGL-11118) and Pradhyumna (JGL-17004) were $1.484 \pm 0.04$ $\mathrm{mm}$ and $1.464 \pm 0.05 \mathrm{~mm}$. And $\mathrm{L} / \mathrm{B}$ ratios are $3.62 \pm 0.16 \mathrm{~mm}$ and $3.37 \pm 0.12 \mathrm{~mm}$. Bhattacharjee and Kulkarni (2000) analyzed some preferred brands of basmati rice and reported that the L/B ratio ranged from 4.47 4.81 .

\section{Volume expansion}

Volume expansion was taken as the ratio between volume of cooked rice and initial volume of raw rice. Volume expansion values of Anjana (JGL-11118) and Pradhyumna (JGL-17004) varieties were $2.7 \mathrm{~cm}$ and 2.5 cm. Shahidullah et al., (2009) reported that the volume expansion ratio (VER) in aromatic traditional rice varieties ranged from 2.364.10, while in basmati varieties it ranged from
2.73-3.63 and they also observed that lower VER is preferred by the consumers than higher VER, on the other hand, higher elongation ratio (ER) of the cooked rice is preferred than lower ER.

\section{Elongation ratio}

Elongation ratios of Anjana (JGL-11118) and Pradhyumna (JGL-17004) rice varieties are 1.45 and 1.48, therefore they have desirable elongation ratios. Elongation ratio is an important parameter for cooked rice. Rice that expands lengthwise gives a finer appearance while that which expands girthwise gives a coarser appearance on cooking (Dipti et al., 2004). An elongation ratio of less than 1.3 is not desirable (Dipti et al., 2004).

Grain elongation on cooking is dependent on genetic factors as well as the degree of milling. Highly polished rice tends to have higher elongation ratio due to less restriction by streaks of bran on the expansion of starch granules (Mohapatra and Bal 2006).

Table.1 Physical properties of two newly released rice varieties of Northern Telangana region

\begin{tabular}{|l|l|l|l|l|l|l|l|l|l|}
\hline $\begin{array}{l}\text { Variety } \\
\text { Name }\end{array}$ & $\begin{array}{l}\text { Accessio } \\
\mathbf{n} \text { No }\end{array}$ & $\begin{array}{l}\text { Grain } \\
\text { Hardne } \\
\text { ss }\end{array}$ & $\begin{array}{l}\mathbf{1 0 0 0} \\
\text { Kernel } \\
\text { weight }\end{array}$ & $\begin{array}{l}\text { Kernel } \\
\text { length } \\
(\mathbf{m m})\end{array}$ & $\begin{array}{l}\text { Kernel } \\
\text { Breadth } \\
(\mathbf{m m})\end{array}$ & $\begin{array}{l}\text { L/B } \\
\text { ratio } \\
(\mathbf{m m})\end{array}$ & $\begin{array}{l}\text { Volume } \\
\text { Expansio } \\
\mathbf{n} \\
\mathbf{( c m})\end{array}$ & $\begin{array}{l}\text { Elongatio } \\
\text { n Ratio } \\
(\mathbf{E R})\end{array}$ & $\begin{array}{l}\text { Wate } \\
\mathbf{r} \text { up } \\
\text { take } \\
\text { ratio } \\
(\boldsymbol{\%})\end{array}$ \\
\hline Anjana & $\begin{array}{l}\text { JGL- } \\
11118\end{array}$ & $\begin{array}{l}5.40 \pm 1.7 \\
8\end{array}$ & $10 \pm 0.03$ & $\begin{array}{l}5.3 \pm 0.2 \\
2\end{array}$ & $\begin{array}{l}1.48 \pm 0.04 \\
4\end{array}$ & $\begin{array}{l}3.62 \pm 0.1 \\
5\end{array}$ & $\begin{array}{l}2.66 \pm 0.05 \\
5\end{array}$ & $1.48 \pm 0.0$ & 225 \\
\hline $\begin{array}{l}\text { Pradhyum } \\
\text { na }\end{array}$ & $\begin{array}{l}\text { JGL- } \\
\text { 17004 }\end{array}$ & $\begin{array}{l}3.78 \pm 1.6 \\
3\end{array}$ & $\begin{array}{l}9.18 \pm 0.1 \\
1\end{array}$ & $\begin{array}{l}4.9 \pm 0.1 \\
3\end{array}$ & $1.46 \pm 0.05$ & $3.3 \pm 0.12$ & $2.5 \pm 0.0$ & $1.45 \pm 0.0$ & 233 \\
\hline
\end{tabular}

Note: Values are expressed as mean \pm Standard deviation of three determinations.

Table. 2 Chemical properties of two newly released rice varieties grown in Northern Telangana region. (Per $100 \mathrm{~g}$ )

\begin{tabular}{|c|c|c|c|c|c|c|c|c|c|c|}
\hline \multirow{2}{*}{$\begin{array}{l}\text { Variety } \\
\text { Name }\end{array}$} & \multirow{2}{*}{$\begin{array}{l}\text { Accession } \\
\text { No }\end{array}$} & \multirow[t]{2}{*}{ Moisture(g) } & \multirow[t]{2}{*}{ Ash (g) } & \multirow[t]{2}{*}{ Protein(g) } & \multirow[t]{2}{*}{ Fat $(g)$} & \multirow{2}{*}{$\begin{array}{l}\text { Fiber } \\
\text { (g) }\end{array}$} & \multirow{2}{*}{$\begin{array}{l}\text { Carbohydrate } \\
\text { (g) }\end{array}$} & \multirow{2}{*}{$\begin{array}{l}\text { Energy } \\
\text { (k.cal) }\end{array}$} & \multicolumn{2}{|c|}{ Minerals } \\
\hline & & & & & & & & & $\begin{array}{l}\text { Iron } \\
(\mathbf{m g})\end{array}$ & \begin{tabular}{|l|} 
Calcium \\
$(\mathrm{mg})$
\end{tabular} \\
\hline & & & & & & & & & $0.93 \pm 0.04$ & $10.3 \pm 0.57$ \\
\hline Pradhyumn: & JGL-17004 & $7.21 \pm 0.12$ & $0.89 \pm 0.02$ & $7.53 \pm 0.2$ & $0.59 \pm 0.06$ & $0.24 \pm 0.05$ & $83.7 \pm 0.07$ & $370.38 \pm 0.64$ & $0.86 \pm 0.06$ & $9.3 \pm 1.15$ \\
\hline
\end{tabular}

Note: Values are expressed as mean \pm Standard deviation of three determinations. 


\section{Water up take by the grains}

The amount of water uptake during cooking process is associated with the appearance of cooked rice. The water uptake ratio of Anjana (JGL-11118) and Pradhyumna (JGL-17004) rice varieties was 225 percent and 233 percent. (Tan et al., 2000) reported that in basmati varieties, water uptake ratio ranged from 280-335 and in aromatic traditional rice varieties $250-350$.

Moisture content of Anjana (JGL-11118) and Pradhyumna (JGL-17004) rice varieties was $7.85 \pm 0.2$ and $7.21 \pm 0.12$. The moisture levels were within the acceptable limit (12\%) for long term stored rice (Adair et al., 1973).

Ash content of Anjana (JGL-11118) and Pradhyumna (JGL-17004) rice varieties was $0.53 \pm 0.13$ and $0.89 \pm 0.02$. The ash content of rice variety Pradhyumna was higher than the ash content of rice variety Anjana. Dipti et al., (2003) reported that ash residual is generally taken to be a measure of the mineral content of materials. High ash content in milled rice is an indication of a good quality of minerals in the rice sample.

The protein content was $7.9 \pm 0.0$ and $7.53 \pm$ $0.2 \mathrm{~g} / 100 \mathrm{~g}$ respectively in Anjana (JGL11118) and Pradhyumna (JGL-17004). Protein values of samples are within the acceptable limits. Protein content of rice can range from 6-15 percent (FAO, 1993). Protein plays an important role in cooked rice texture due to formation of a complex with starch that impairs the swelling of starch granule. Starch granule swelling affects both viscosity intensity and the rate of starch gelatinization. Protein content can vary with the degree of milling (Suwannaporn, 2007).

The fat content was $0.55 \pm 0.08$ and $0.59 \pm$ $0.06 \mathrm{~g} / 100 \mathrm{~g}$ respectively in Anjana (JGL11118) and Pradhyumna (JGL-17004).
Okaka, (2005) reported that higher fat content exposes the grains to spoilage during storage due to oxidation. Since the fat content of samples are within the acceptable limits, grain spoilage is less. Crude fibre of samples ranged from $0.39 \pm 0.10$ and $0.24 \pm 0.05 \mathrm{~g} / 100$ g.

Carbohydrate content of Anjana (JGL-11118) and Pradhyumna (JGL-17004) rice varieties was $83.11 \pm 0.62$ and $83.7 \pm 0.07$. Energy values of Anjana (JGL-11118) and Pradhyumna (JGL-17004) rice varieties were $369.45 \pm 0.64$ and $370.38 \pm 0.62 \mathrm{kcal} / 100 \mathrm{~g}$.

Iron content of rice varieties Anjana (JGL11118) and Pradhyumna (JGL-17004) was $0.93 \pm 0.04$ and $0.86 \pm 0.04 \mathrm{mg} / 100 \mathrm{~g}$. These values are within the range 0.2 to $2.8 \mathrm{mg} / 100$ g reported by (Kennedy et al., 1975). Calcium content was $9.3 \pm 1.15$ and $10.3 \pm 0.5 \mathrm{mg} / 100$ $\mathrm{g}$ respectively in Anjana (JGL-11118) and Pradhyumna (JGL-17004). Presence of Calcium in rice is a clear indication that when consumed, it will aid normal development and maintenance of bones and teeth, clotting of the blood, nerve irritability in the blood (Alaka and Okaka, 2011). If rice is taken as a staple food in large quantity compared to other foods, there will be sufficient contribution of minerals through diet.

The physical characteristics of two rice varieties tested are quite good. Their grain size was long, and their appearance which is an important index of quality is good. Their proximate composition and minerals were all within acceptable levels. Therefore, the varieties are of good quality.

\section{References}

Adair, C. R., Bollich, C. N., Bowman, D. H., Jodon, T. H., Webb, B. D and. Atkins, J. G. 1973. Rice Breeding and testing Method in the United States. In: Rice in 
the United States Varieties and Production. United States Department. Agriculture Handbook. 22-27.

Alaka, I.C., and Okaka, J. C. 2011. Physicochemical and milling characteristics of some selected locally processed rice in south eastern Nigeria. Journal of Science and Technology. 17 (1): 20-32.

AOAC, 2005. Official methods of analysis of the AOAC International.16 432 (Ed.), Supplement 1998. AOAC Washington, DC. USA. 25-28.

Betres-Marquez, S. P., Jensen, H. H. and Upton, J. L. 2005. Trends in rice consumption and contribution of rice to the total diet of Americans. In: Abstract presented at Texas Dietetic Association Meeting, April, 2005.

Bhattacharjee, P., and Kulkarni P. R. 2000. A comparative study on the physical characteristics and cooking quality parameters of commercial brands of basmati rice. International Journal of Food Sciences and Nutrition. 51: 295299.

Cruz, N.D., and Kush, G. S. 2000. Rice grain quality evaluation procedures.15-28. In: Singh, R.K., Singh, U.S. and Khush, G.S. (Ed.). Aromatic rices. Oxford and IBH Publishing Co. Pvt. Ltd. New Delli, India.

Diako, C., Manful, J. T. Johnson, P. N. T., Dawson, B., Bediako, A and Saalia, F. K. 2011. Physicochemical Characterization of Four Commercial Rice Varieties in Ghana. Journal of Food Science and Technology. 3 (3): 196-202.

Dipti, S. S., Bari, M. N and Kabir, K. A. 2003. Grain Quality Characteristics of some Beruin Rice Varieties of Bangladesh. Pakistan Journal of Nutrition. 2 (4): 242-245.

Dipti, S. S., Hossain, S. T., Bari, M. N and Kabir, K. A. 2002. Physicochemical and
Cooking Properties of some fine rice varieties. Pakistan Journal of Nutrition 1 (4): 188-190.

Dipti, S. S., Hossain, S. T., Bari, M. N. and Kabir, K. A. 2004. Physicochemical and cooking properties of some fine rice varieties. Pakistan Journal of Nutrition. 1 (4): 188-190.

Food and Agricultural organization of the United Nations. FAOSTAT database. 2014. http://fao.org/site/362.

Food and Agricultural Organization of the United Nations (FAO). 2004. Rice is Life.

ftp://ftp.fao.org/docrep/fao/008/y5682 e/y5682e00.pdf

Food Fortification Initiative (FFI). 2014. Rice fortification's impact on nutrition. Atlanta, USA: FFI. http://www.ffinetwork.org/

Gopalan, C., Ramasastri, B. V and Balasubramanian, S. C. 2004. Nutritive Value of Indian Foods. National Institute of Nutrition, ICMR, Hyderabad.

Kourtroubas, S. D., Mazzani, F., Pons, E and Ntanos, D. A. 2004. Grain quality variation and relationships with morphological traits in rice genetic resources in Europe. Field Crop Research. 86115-86130.

Meena, S. K., Vijayalakshmi, D., Ravindra, U. 2010. Physical and Cooking Characteristics of Selected Aromatic Rice Varieties. Journal of Dairying, Foods and Home Sciences. 29: 227-231.

Mohapatra, D., and Bal, S. 2006. Cooking quality and instrumental textural attributes of cooked rice for different milling fractions. Journal of Food Engineering. 73: 253-259.

Okaka, J. C., 2005. Handling Storage and Processing of Plant Foods. Food Analysis and Instrumentation Theory and Practice. 120-135.

Rhoades, A., 2008. Basmati rice - the quality 
grain. Asian Agricultural-History. 12 (2): 93-108.

Sahay, K. M., and Singh, K. K. 2005. Unit operations of agricultural processing. Second revised vikas publishing house. Pvt. Ltd. second reprint.273.

Shahidullah, S. M., Hanafi, M. M., Ashrafuzzaman, M., Ismail, M. R and Khair, A. 2009. Genetic diversity in grain quality and nutrition of aromatic rice's. African Journal of Biotechnology. 8 (7): 1238-1246.

Shobha, R. N., Sheshu, M., Manish, K. P., Sundaram., R. M., Prasad, G. S., Sudharshan, I., Subba Rao., L. V and Ravindrababu, V. 2008. Genetics and molecular approaches for improvement of grainquality traits in rice. Indian Journal of Crop Science. 3(1): 1-14.
Siong, T. E., Wan Choo, K. S and Shahid, S. M. 1989. Determination of calcium in foods by the Tritrimetric methods. Division of Human Nutrition. 12 (3): 303-311.

Snedecor, G. W., and Cochran, W. G. 1983. Stastical methods, Oxford and IBH publishing company, New Delhi.

Suwannaporn, P., Pitiphunpong, $\mathrm{S}$ and Champangern, S. 2007. Classification of rice amylase content by discriminant analysis of physicochemical properties. Journal of Starch. 59: 61-67.

Tan, Y. F., Xing, Y. Z., Li, J.X., Yu, S. B., Xu, C. G and Zhang, Q. 2000. Genetic bases of appearance quality of rice grains in Shanyou 63 an elite rice hybrid. Theoretical and Applied Genetics. 101: 823-829.

\section{How to cite this article:}

Anitha, R., K. Manorama, CH. Hemamalini and Sreedhar, M. 2017. Physical and Chemical Properties of Selected Newly Released Rice Varieties of Northern Telangana Region. Int.J.Curr.Microbiol.App.Sci. 6(9): 2873-2879. doi: https://doi.org/10.20546/ijcmas.2017.609.353 